\title{
Carbodiimide modification enhances activity of pig pancreatic phospholipase $A_{2}$
}

\author{
João Paulo M. FERREIRA ${ }^{2}$, Ram SASISEKHARAN ${ }^{1,3,4}$, Otway LOUIE ${ }^{1}$ and Robert LANGER ${ }^{1,3}$ \\ 1 Department of Chemical Engineering, Massachusetts Institute of Technology, USA \\ ${ }^{2}$ Escola Superior de Biotecnologia, Universidade Catolica Portuguesa, Portugal \\ ${ }^{3}$ Harvard Massachusetts Institute of Technology, Division of Health Sciences and Technology, USA \\ ${ }^{4}$ Division of Medical Sciences, Harvard Medical School, USA
}

\begin{abstract}
Pig phospholipase $A_{2}$, pig iso-phospholipase $A_{2}$ and bovine pancreatic phospholipase $A_{2}$ were reacted in solution with 1-ethyl-3-(3-dimethylaminopropyl)carbodiimide, in the presence of $\mathrm{N}$-hydroxysulfosuccinimide, at $\mathrm{pH} 7$. The influence of micellar protectants was analyzed. In the presence of $n$-hexadecylphosphocholine, the losses of activity in micellar diheptanoyl-lecithin were 80,35 , and $10 \%$ in bovine phospholipase $A_{2}$, pig iso-phospholipase $A_{2}$, and pig phospholipase $A_{2}$, respectively. With 1-oleoylglycerophosphocholine, the bovine enzyme lost $40 \%$ activity, but the pig enzyme was activated sevenfold. The modified pig enzyme showed pre-micellar activation on monomeric diheptanoyl-lecithin, and either reduced or increased activities on mixed micelles of bile salt with egg phosphatidylcholine, depending on the composition of the micelles. This activation is consistent with previous protein-engineering studies of pig pancreatic phospholipase $A_{2}$. In this study, we present new information concerning the specificity and interfacial recognition behaviour of this enzyme in relation to this activation.
\end{abstract}

Sources of extracellular phospholipases $\mathrm{A}_{2}\left(\mathrm{PLA}_{2}\right)$ include mammalian pancreas, cobra and other snake venoms (Waite, 1987). These enzymes act preferentially on phospholipids present at interfaces. This phenomenon, known as interfacial recognition, is not well understood and has instigated detailed structural characterization of these enzymes. In particular, chemical modification studies that assigned the functionality of several different residues have been conducted (Verheij et al., 1981). In one of these studies, the reaction of water-soluble 1-ethyl-3-(3-dimethylaminopropyl)carbodiimide hydrochloride (EDC) with bovine pancreatic $\mathrm{PLA}_{2}$ showed that Asp49, a well-conserved residue in $\mathrm{PLA}_{2}$ proteins, is involved in the binding of the cofactor calcium (Fleer et al., 1981).

Previously, we have used a modification of the carbodiimide method for covalent immobilization of $\mathrm{PLA}_{2}$ (Ferreira et al., 1993). Mild reaction conditions were employed, with the $\mathrm{pH}$ increased to $\mathrm{pH} 7.0$ and using $N$-hydroxysulfosuccinimide as a reaction enhancer (Staros et al., 1986). In the present study, modification in the soluble form of pancreatic $\mathrm{PLA}_{2}$ proteins under similar reaction conditions is investi-

Correspondence to $\mathrm{R}$. Langer, Massachusetts Institute of Technology, Room E25-342, 77 Massachusetts Av., Cambridge, MA 02139, USA

Fax: +16172588827 .

Abbreviations. PLA $\mathrm{A}_{2}$, phospholipase $\mathrm{A}_{2}$; EDC, 1-ethyl-3-(3dimethylaminopropyl)carbodiimide hydrochloride; CMEC, 1-cyclohexyl-3-(2-morpholinoethyl)carbodiimide metho- $p$-toluenesulfonate; Pam $P$ Cho, $n$-hexadecylphosphocholine; PtdCho, phosphatidylcholine; OleGroPCho, 1-(cis-9-octadecenoyl)-sn-glycero-3-phosphocholine; (Hpo $)_{2}$ GroPCho, 1,2-diheptanoyl-sn-glycero-3-phosphocholine.

Enzyme. Phospholipase $\mathrm{A}_{2}$ (EC 3.1.1.4). gated. Different variables are analyzed, such as $\mathrm{pH}$, micellar protectants, and different nucleophiles. Pig PLA 2 , pig iso$\mathrm{PLA}_{2}$ and bovine pancreatic PLA $\mathrm{PL}_{2}$ are compared. In each case, activities in micellar short-chain lecithin are determined. Under certain conditions, the pig enzyme showed a several-fold activation. The results are compared with data from previous enzyme-engineering studies.

\section{MATERIALS AND METHODS}

\section{Enzyme preparation}

Pig pancreatic $\mathrm{PLA}_{2}$ was purchased from Boehringer Mannheim as a suspension in $3.2 \mathrm{M}$ ammonium sulfate. This preparation was extensively dialyzed against cold deionized water. To destroy any trypsin activity, the dialyzed solution was heated at $65^{\circ} \mathrm{C}$ for $1 \mathrm{~h}$. This treatment did not affect activity, but increased the enzyme stability in solution. Concentrated solutions were aliquoted and stored frozen. Bovine pancreatic $\mathrm{PLA}_{2}$ was obtained as a lyophilized powder from Sigma.

\section{Other materials}

$N$-Hexadecylphosphocholine (PamPCho) was a product of Calbiochem and all other phospholipids were from Avanti Polar Lipids. 1-Ethyl-3-(3-dimethylaminopropyl)carbodiimide hydrochloride and $N$-hydroxysulfosuccinimide were from Pierce, and 1-cyclohexyl-3-(2-morpholinoethyl)carbodiimide metho- $p$-toluenesulfonate (CMEC) was from Aldrich. All other chemicals were of the highest purity available. 


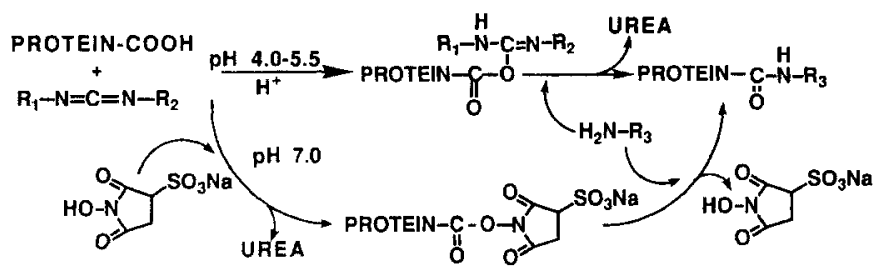

Fig. 1. Modification of protein carboxylic groups with carbodiimides. Pathways in the absence (upper) and presence (lower) of $\mathrm{N}$ hydroxysulfosuccinimide as an enhancer are shown.

\section{Separation of isoforms}

The commercial preparation of pig pancreatic $\mathrm{PLA}_{2}$ was subjected to reverse-phase high-performance liquid chromatography (Hewlett Packard, LC 1090) in a Vydac $C_{4}$ column $(0.46 \mathrm{~mm} \times 25 \mathrm{~mm})$ using a gradient of $0.1 \%$ trifluoroacetic acid (solvent $\mathrm{A}$ ) and $80 \%$ acetonitrile/ $0.085 \%$ trifluoroacetic acid (solvent B) as follows: $2-30 \%$ solvent $B$ for $0-$ $15 \mathrm{~min} ; 30-75 \%$ solvent $\mathrm{B}$ for $15-90 \mathrm{~min} ; 75-99 \%$ solvent B for $90-100 \mathrm{~min}$; isocratic elution at $99 \%$ solvent $\mathrm{B}$ for $100-110 \mathrm{~min}$. This was followed by a $20-\mathrm{min}$ equilibration at $2 \%$ solvent $B$. The flow rate was $0.72 \mathrm{ml} / \mathrm{min}$. The peaks corresponding to the two isoforms were collected, dried on a speed-vacuum concentrator (Heto, Denmark), and redissolved in MilliQ water. The identification of isoforms was performed by peptide sequencing of the first 19 residues of both proteins, using an Applied Biosystems model 477 protein sequencer.

\section{Protein concentrations}

The protein content in solution was determined by measuring the absorbance at $280 \mathrm{~nm}$, using $A^{1 \%}=13$ for all pancreatic enzymes (Jain et al., 1991), or by the microbicinchoninic acid assay (Pierce); the calibration for this assay was carried out with pig $\mathrm{PLA}_{2}$ at a known concentration.

\section{Enzyme modification}

Unless otherwise specified, modification reactions were carried out in $15 \mathrm{mM}$ Mops, $150 \mathrm{mM} \mathrm{CaCl}_{2}, 0.5 \mathrm{M}$ taurine, $\mathrm{pH} 7.0$, containing $5 \mathrm{mM}$ 1-(cis-9-octadecenoyl)-sn-glycero3-phosphocholine (OleGroPCho); the $\mathrm{PLA}_{2}$ concentration was $60 \mu \mathrm{g} / \mathrm{ml}(4.3 \mu \mathrm{M})$. Reactions were initiated by adding $N$-hydroxysulfosuccinimide and EDC from freshly prepared stock solutions in water, to give final concentrations of $4 \mathrm{mM}$ and $30 \mathrm{mM}$, respectively. The $\mathrm{pH}$ was immediately adjusted to $\mathrm{pH} 6.95-7.0$, and the reaction was monitored for the following 5-10 $\mathrm{min}$ at this value. Mixtures were allowed to stand overnight. These conditions are designated the standard conditions.

\section{Separation of modified enzyme}

Reaction mixtures were first concentrated in a centrifugal concentrator (Amicon) and subjected to reverse-phase HPLC. The column and elution conditions were the same as those used in the separation of pig PLA $\mathrm{PL}_{2}$ isoforms (see above). The modified enzyme was collected, dried, and redissolved in MilliQ water.

\section{Activity assays}

$\mathrm{PLA}_{2}$ activities were always measured titrimetrically (Waite, 1987). Assays with 1,2-diheptanoyl-sn-glycero-3-
Table 1. Effect of pH and micellar protectant during modification of pig PLA $\mathbf{A}_{2}$. Standard modification conditions were used, except that $N$-hydroxysulfosuccinimide was omitted at $\mathrm{pH} 5.0$. Activities were measured in $8 \mathrm{mM}(\mathrm{Hpo})_{2} \mathrm{GroPCho}$, and represent averages of two or more independent experiments, differing by no more than $10 \%$.

\begin{tabular}{lll}
\hline $\mathrm{pH}$ & Micellar protectant & Specific activity \\
\hline & & $\mu \mathrm{mol} \cdot \mathrm{min}^{-1} \cdot \mathrm{mg}^{-1}$ \\
Native & - & 92 \\
5.0 & - & 12 \\
5.0 & PamPCho & 43 \\
5.0 & OleGroPCho & 56 \\
7.0 & - & 23 \\
7.0 & PamPCho & 84 \\
7.0 & OleGroPCho & 875 \\
\hline
\end{tabular}

phosphocholine $\left[(\mathrm{Hpo})_{2} \mathrm{Gro} P \mathrm{Cho}\right]$ were carried out in $1 \mathrm{mM}$ borate ( $\mathrm{pH} 8.0$ ) or $1 \mathrm{mM}$ Mes ( $\mathrm{pH} 6.0), 0.1 \mathrm{M} \mathrm{NaCl}, 25 \mathrm{mM}$ $\mathrm{CaCl}_{2}$, at $\mathrm{pH} 8.0$ and $31^{\circ} \mathrm{C}$. Mixed micelles of sodium cholate and egg PtdCho were prepared by vortexing lyophilized lecithin in $1 \mathrm{mM}$ borate, $0.1 \mathrm{M} \mathrm{NaCl}, 10 \mathrm{mM} \mathrm{CaCl}_{2}$, containing $10 \mathrm{mM}$ or $50 \mathrm{mM}$ sodium cholate; assays were performed at $\mathrm{pH} 8.0$ and $25^{\circ} \mathrm{C}$ in $2 \mathrm{ml}$. For each sample, the average values of two or more assays, differing by no more than $10 \%$, were determined. Furthermore, for any set of conditions, the values represent averages of two or more independent experiments.

\section{RESULTS}

\section{Effect of pH and micellar protectant}

When pig pancreatic $\mathrm{PLA}_{2}$ was reacted with water-soluble EDC, the activity of the modified protein depended strongly on $\mathrm{pH}$. Table 1 shows activities with micellar (Hpo)${ }_{2}$ GroPCho as substrate for the enzyme modified at both $\mathrm{pH} 5.0$ and $\mathrm{pH} 7.0$. In the absence of any micellar protectant, the modified enzyme had $13-25 \%$ residual activity. Inclusion of OleGroPCho or PamPCho in the reaction media protected the enzyme against deactivation. At $\mathrm{pH} 5.0$, and in the presence of lipids, approximately $45-60 \%$ residual activity was observed. When the enzyme was modified at $\mathrm{pH} 7$, and protected by PamPCho, this value increased to $90 \%$. Surprisingly, in the presence of OleGroPCho, the modified enzyme had average activity $875 \pm 62 \quad(n=8)$, compared with $92 \pm 6 \mathrm{U} / \mathrm{mg}$ for the native enzyme.

\section{Effect of protein concentration}

When all other variables were kept constant, the specific activity of the bulk reaction mixture varied with protein concentration (Fig. 2). Decreasing protein concentrations increased the specific activity against micellar (Hpo $)_{2}^{-}$ GroPCho up until approximately $100 \mu \mathrm{g} / \mathrm{ml}$; no further increase was observed at lower concentrations. Reaction mixtures above $100 \mu \mathrm{g} / \mathrm{ml}$ were subjected to reverse-phase HPLC for separation of the modified enzyme; after recovery, the peaks of the modified enzyme had similar activities to enzyme modified at less than $100 \mu \mathrm{g} / \mathrm{ml}$.

\section{Effect of carbodiimide and $\boldsymbol{N}$-hydroxysulfosuccinimide}

A second carbodiimide, CMEC, was used for modification of pig $\mathrm{PLA}_{2}$, both in the presence and absence of $\mathrm{N}$ - 


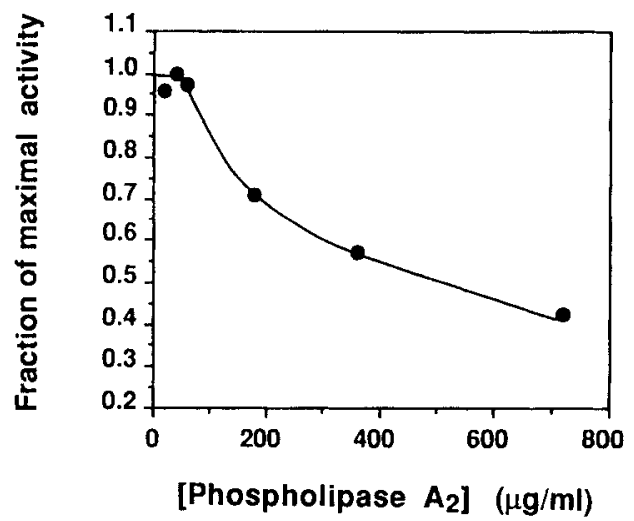

Fig. 2. Effect of pig PLA $\mathrm{A}_{2}$ on activity of bulk reaction mixture. All other conditions were standard (see Materials and Methods section). Activities were measured in $8 \mathrm{mM}(\mathrm{Hpo})_{2} \mathrm{Gro} P \mathrm{Cho}$. The estimated errors are less than $10 \%$.

Table 2. Effect of carbodiimide and $N$-hydroxysulfosuccinimide on the modification of pig PLA $\mathbf{A}_{2}$. Activities were measured in $8 \mathrm{mM}(\mathrm{Hpo})_{2} \mathrm{Gro} P \mathrm{Cho}$, and represent averages of two or more experiments differing by no more than $10 \%$. The carbodiimide and $N$-hydroxysulfosuccinimide concentrations were $30 \mathrm{mM}$ and $4 \mathrm{mM}$, respectively.

\begin{tabular}{lll}
\hline $\begin{array}{l}\text { Carbo- } \\
\text { diimide }\end{array}$ & $\begin{array}{l}N \text {-Hydroxy-sulfo- } \\
\text { succinimide }\end{array}$ & Specific activity \\
\hline & & $\mu \mathrm{mol} \cdot \mathrm{min}^{-1} \cdot \mathrm{mg}^{-1}$ \\
CMEC & - & 128 \\
CMEC & + & 506 \\
EDC & - & 522 \\
EDC & + & 875 \\
\hline
\end{tabular}

Table 3. Effect of nucleophile in modification of pig pancreatic PLA $_{2}$. Standard modification conditions were used, except that the nucleophile was varied. Activities were measured in $8 \mathrm{mM}(\mathrm{Hpo})_{2}$. GroPCho. Estimated errors are less than $10 \%$.

\begin{tabular}{ll}
\hline Nucleophile & Specific activity \\
\hline & $\mu \mathrm{mol} \cdot \mathrm{min}^{-1} \cdot \mathrm{mg}^{-1}$ \\
Taurine & 875 \\
Ethanolamine & 851 \\
Diaminepropane & 561 \\
Glycine ethyl ester & 113 \\
Heptylamine & 32 \\
\hline
\end{tabular}

hydroxysulfosuccinimide (Table 2). However, the greatest activation was observed with EDC and $N$-hydroxysulfosuccinimide. CMEC with $N$-hydroxysulfosuccinimide led to lower activation. EDC alone was able to activate the enzyme to a great extent, but CMEC alone did not significantly increase enzyme activity. These results suggest different yields of the modified, activated form of the enzyme.

\section{Effect of different nucleophiles}

The activities of pig $\mathrm{PLA}_{2}$ reacted in the presence of different nucleophiles are shown (Table 3 ). Highest activation was observed with taurine, followed by ethanolamine, di-

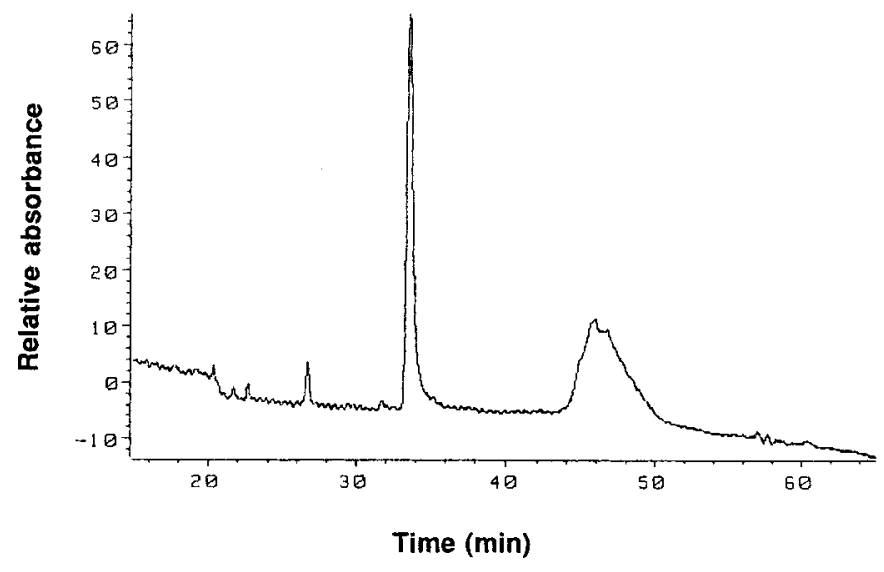

Fig. 3. Separation of modified enzyme by reverse-phase HPLC. Chromatogram of a mixture of native and modified pig PLA . The native and modified peaks are centered at $34 \mathrm{~min}$ and $46 \mathrm{~min}$, respectively.

Table 4. Modification of different pancreatic $\mathbf{P L A}_{2}$ enzymes. Activities were measured in $8 \mathrm{mM}(\mathrm{Hpo})_{2} \mathrm{Gro} P \mathrm{Cho}$, and represent averages of two or more independent experiments differing by no more than $10 \%$.

\begin{tabular}{lll}
\hline Micellar protectant & \multicolumn{2}{l}{ Specific activity of } \\
\cline { 2 - 3 } & bovine $\mathrm{PLA}_{2}$ & pig iso-PLA \\
\hline & $\mu \mathrm{mol} \cdot \mathrm{min}^{-1} \cdot \mathrm{mg}^{-1}$ \\
\hline & 50 & 535 \\
Native & 10 & 352 \\
PamPCho & 29 & 695 \\
OleGroPCho & & \\
\hline
\end{tabular}

aminepropane and glycine ethyl ester. In the presence of heptylamine, deactivation was observed.

\section{Reaction with different PLA enzymes $_{2}$}

The activities of other pancreatic PLA $\mathrm{P}_{2}$ enzymes, reacted under similar conditions, are shown in Table 4 . When OleGroPCho was used as a protectant, pig iso-PLA $\mathrm{P}_{2}$ was activated by only $30 \%$, and the bovine enzyme was deactivated

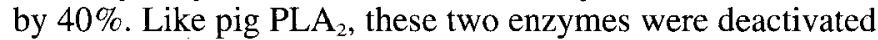
with $\mathrm{Pam} P \mathrm{Cho}$ as a micellar protectant.

\section{Isolation of modified enzyme}

Reverse-phase HPLC was used to isolate the activated, modified form of the enzyme from the non-activated form, and from OleGroPCho. The modified enzyme has higher hydrophobicity, eluting as a relatively broad peak, at higher acetonitrile concentrations than the native enzyme (Fig. 3).

\section{Kinetic studies}

Fig. 4 shows the activity/concentration profiles for native and modified (reverse-phase HPLC purified) pig PLA against ( $\mathrm{Hpo})_{2} \mathrm{Gro} P \mathrm{Cho}$. As expected, the native enzyme had close to background activities at monomeric concentrations of $(\mathrm{Hpo})_{2} \mathrm{GroPCho}(<1.5 \mathrm{mM})$, and a pseudo MichaelisMenten behavior in the micellar region, with $V_{\max } 126 \mathrm{U} / \mathrm{mg}$ 
Table 5. Effect of $\mathrm{pH}$ on activities of native and modified pig $\mathbf{P L A}_{2}$ and pig iso-PLA $\mathbf{A}_{2}$. Activities were measured in $8 \mathrm{mM}(\mathrm{Hpo})_{2-}$ GroPCho. Estimated errors are less than $10 \%$.

\begin{tabular}{|c|c|c|}
\hline \multirow[t]{2}{*}{$\mathrm{PLA}_{2}$} & \multicolumn{2}{|c|}{ Activity at } \\
\hline & $\mathrm{pH} 6.0$ & $\mathrm{pH} 8.0$ \\
\hline & \multicolumn{2}{|c|}{$\mu \mathrm{mol} \cdot \min ^{-1} \cdot \mathrm{mg}^{-1}$} \\
\hline Pig, native & 128 & 92 \\
\hline Pig, modified & 586 & 875 \\
\hline Pig iso-PLA ${ }_{2}$, native & 404 & 535 \\
\hline Pig iso-PLA ${ }_{2}$, modified & 484 & 695 \\
\hline
\end{tabular}

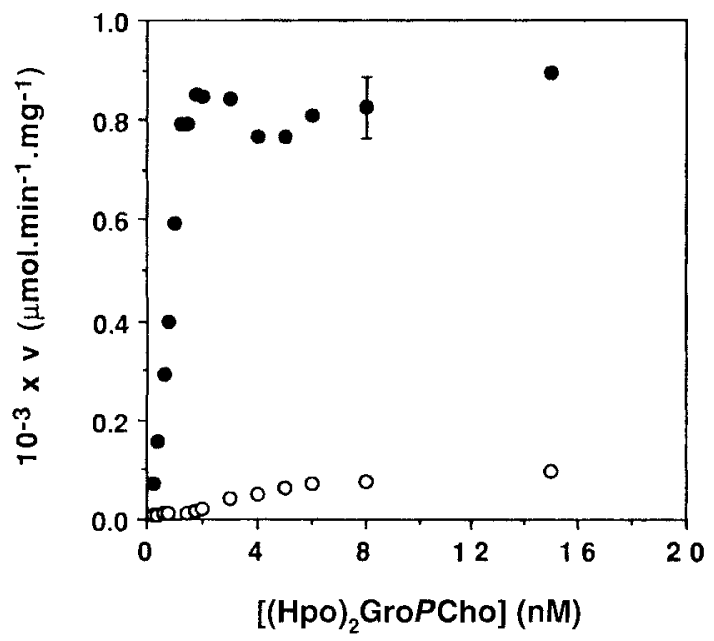

Fig. 4. Activity/concentration profiles in $(\mathrm{Hpo})_{2} \mathrm{GroPCho}$. Initial hydrolysis rates for native $(O)$ and modified $(O)$ pig PLA $_{2}$ at varying concentrations of substrate. The error bar represents \pm SD of activities for eight independent modification experiments.

and an apparent Michaelis constant, $K_{\text {app }} 3.85 \mathrm{mM}$ (in micellar concentration). These values are in agreement with other studies (Kuipers et al., 1989). The modified enzyme had a striking profile (Fig. 4). The activity increased rapidly with concentration in the monomeric region, attained a maximum at the approximate critical micellar concentration $(1.5 \mathrm{mM})$, and showed no further increase in the micellar region. Thus, the $k_{\text {cat }}$ of the modified enzyme was sevenfold higher than the value of the native enzyme.

The activities at $\mathrm{pH} 6.0$ and $\mathrm{pH} 8.0$ in micellar $(\mathrm{Hpo})_{2}-$ GroPCho were compared, for native and modified forms of

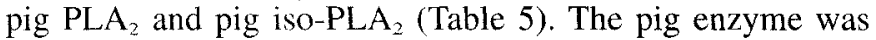
more active at $\mathrm{pH} 6.0$, but modified pig $\mathrm{PLA}_{2}$, and native and modified pig iso- $\mathrm{PLA}_{2}$ were more active at $\mathrm{pH}>7$.

Other interesting observations occurred in the kinetics for mixed micelles of bile salts and egg PtdCho (Table 6). Modi-

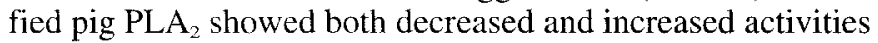
with these micelles, depending upon the ratio of bile salt/egg PtdCho. At low ratios ( $2: 1$ molar), modification lowered the $k_{\text {cat }}$ value; at high bile salt concentration (10:1), the modified enzyme was $4-5$ times as active as the native enzyme. Pig iso-PLA ${ }_{2}$ had a similar behavior, but activity of the modified form in the high bile salt concentration micelles was less than two times the native value.
Table 6. Activities of native and modified pancreatic PLA $\mathrm{A}_{2}$ in mixed micelles of sodium cholate with egg PtdCho. Values are initial rates of reaction, and represent averages \pm SD of two or more independent experiments.

\begin{tabular}{|c|c|c|}
\hline \multirow[t]{2}{*}{$\mathrm{PLA}_{2}$} & \multicolumn{2}{|c|}{ Cholate/egg PtdCho } \\
\hline & $10 \mathrm{mM} / 5 \mathrm{mM}$ & $50 \mathrm{mM} / 5 \mathrm{mM}$ \\
\hline & \multicolumn{2}{|c|}{$\mu \mathrm{mol} \cdot \min ^{-1} \cdot \mathrm{mg}^{-1}$} \\
\hline Pig, native & $1143 \pm 75$ & $42 \pm 2$ \\
\hline Pig, modified & $496 \pm 18$ & $199 \pm 2$ \\
\hline Pig iso-PLA ${ }_{2}$, native & $947 \pm 81$ & $95 \pm 3$ \\
\hline Pig iso-PLA ${ }_{2}$, modified & $555 \pm 42$ & $177 \pm 25$ \\
\hline
\end{tabular}

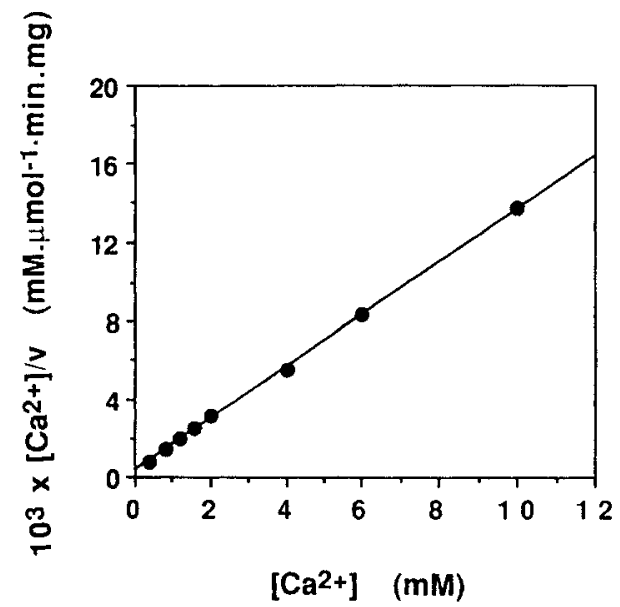

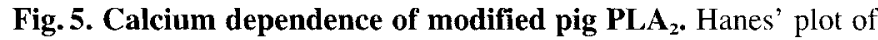
the activity of modified pig $\mathrm{PLA}_{2}$ as a function of calcium concentration. Assays were carried out in $1 \mathrm{mM}$ borate, $0.1 \mathrm{M} \mathrm{NaCl}, 8 \mathrm{mM}$ $(\mathrm{Hpo})_{2} \mathrm{Gro} P \mathrm{Cho}, \mathrm{pH} 8.5$, and $31^{\circ} \mathrm{C}$. Estimated errors of activities are less than $10 \%$.

\section{Dependence of activity on calcium concentration}

The Hanes' plot $([\mathrm{Ca}] / V$ versus $[\mathrm{Ca}])$ of the dependence of enzymic activity on calcium concentration for the modified enzyme is shown in Fig. 5. All data in the $0-10 \mathrm{mM}$ calcium range are fitted with one straight line, indicating the existence of a single calcium-binding site. An apparent dissociation constant value of $K_{\mathrm{Ca}} 0.24 \mathrm{mM}$ was estimated.

\section{DISCUSSION}

Chemical modification of carboxylic groups in proteins is frequently carried out using water-soluble carbodiimides as activators, forming an $O$-acylisourea intermediate that reacts with a nucleophile (Hoare and Koshland, 1967). In the presence of $\mathrm{N}$-hydroxysulfosuccinimide, the reaction leads to the formation of a $N$-hydroxysulfosuccinimide ester of the carboxylic group (Fig. 1), that is displaced by strong nucleophiles (Staros et al., 1986; Staros, 1988). This ester is more resistant to hydrolysis than the $O$-acylisourea adduct, thus permitting higher yields in the final aminolysis step (Staros, 1988 ). Both ester formation and aminolysis reactions proceed at $\mathrm{pH}$ values of approximately $\mathrm{pH} 7$.

Using this chemistry, and in the presence of OleGroPCho as protectant, a modified form of pig pancreatic enzyme that 
was the sevenfold more active toward small micelles than native enzyme was obtained. Under analogous reaction conditions, bovine $\mathrm{PLA}_{2}$ was not activated, and pig iso-PLA was activated by $30 \%$ (this slight activation results, most likely, from the presence of some pig isoform in the preparation). Comparing the sequences of the three enzymes, pig $\mathrm{PLA}_{2}$ has a glutamate residue at position 71 , where the bovine enzyme and pig iso-enzyme have an asparagine residue. There is no additional carboxylic group in pig $\mathrm{PLA}_{2}$ without an equivalent (group) in either the bovine enzyme or pig isoenzyme. The fact that activation occurred in the presence of micellar phospholipid suggests that the underlying modification involves residue(s) of the interfacial recognition site. The X-ray crystal structure of the pig enzyme indicates that several residues of the loop at positions 62-72 are involved in interfacial binding (Dijkstra et al., 1983), thus reinforcing the hypothesis of Glu71 modification. Glu 71 is involved in the binding of a second calcium ion, which is responsible for the effective enzyme interaction with organized lipid interfaces at alkaline $\mathrm{pH}>7$ (Donnée-Op den Kelder et al., 1983). A mutant pig PLA P $_{2}$ with Glu71 substituted by an asparagine residue (van den Bergh et al., 1989) lacked the second calcium-binding site. Analogously, this carbodiimidemodified enzyme has only one calcium-binding site, as shown by the dependence of enzymic activity upon calcium. concentration (Fig. 5). For native pig pancreatic $\mathrm{PLA}_{2}$, the Hanes' plot shows a transition between two different slopes at 1-2 mM calcium (van den Bergh et al., 1989). Furthermore, the $V_{\max }$ value in micellar dioctanoyl-lecithin of the modified enzyme $\left(4821 \mathrm{U} / \mathrm{mg}\right.$, at $25^{\circ} \mathrm{C}$ ) was nearly identical to the value reported for the above mutant $(5043 \mathrm{U} / \mathrm{mg}$; van den Bergh et al., 1989).

Micellar OleGro $P$ Cho can promote modification of a residue in the vicinity of the interfacial binding site in two ways. Either the binding to the interface changes its environment and/or conformation, making it more reactive, or EDC can partition to OleGroPCho micelles, and thus facilitate contact with that residue. Meyer et al., while performing tyrosine modification in pancreatic PLA $_{2}$ enzyme, found that tetranitromethane was incorporated into lysophosphatidylcholine micelles, resulting in a higher rate of modification (Meyer et al., 1979). The fact that activation is observed when the enzyme is modified at $\mathrm{pH} 7.0$, and not at $\mathrm{pH} 5.0$, can also result from this partitioning. It is likely that the surface charge of the micelle is different at these two $\mathrm{pH}$ values, favoring partitioning of the positively charged carbodiimides at $\mathrm{pH} 7$. It is interesting, however, that activation was not observed with PamPCho as a micellar protectant. The same partitioning effect could still be the reason for the lower reactivity of the carbodiimide CMEC compared to EDC (Table 2). Alternatively, the presence of two bulky rings in the structure of CMEC may hinder the access to the residue responsible for the activation.

Carbodiimides can also attack tyrosine residues, forming an $O$-arylisourea adduct that is quite stable at $\mathrm{pH} 7$ and $\mathrm{pH}<7$ (Carraway and Koshland, 1968). As phenolic groups are more reactive at higher $\mathrm{pH}$ values, the possibility of the carbodiimide attacking the neighboring Tyr69 or Tyr63 cannot be completely excluded. However, the data suggests that tyrosine modification, if it occurs, is not the primary reason for activation. For instance, $N$-hydroxysulfosuccinimide does enhance the yield of modified enzyme, as observed with CMEC (Table 2). Based on the proposed reaction mechanism (Staros et al., 1986), $N$-hydroxysulfosuccinimide is unlikely to interfere with the $O$-arylisourea derivative.
A plausible reason for the increased catalytic activity of modified pig $\mathrm{PLA}_{2}$ is the change in the conformation of the loop at positions $62-72$, involved in interfacial binding. Cobra venom enzymes have higher turnover numbers than the pancreatic enzymes, and they lack some residues of that loop (Kuipers et al., 1989). A mutant pig PLA $_{2}$ lacking residues 62-66 had a $k_{\text {cat }}$ against micellar'(Hpo) $)_{2}$ GroPCho 16 times higher than the native enzyme (Kuipers et al., 1989). Another site-directed-mutagenesis study of bovine pancreatic $\mathrm{PLA}_{2}$ (Noel et al., 1991) showed that replacement of Lys56 by a neutral or hydrophobic residue imparted different conformations in that same loop, with a 3-4-fold improvement in the $k_{\text {cat }}$ in short-chain lecithin micelles.

The modified pig PLA $_{2}$ had approximately $50 \%$ native activity in $10 \mathrm{mM}$ cholate $/ 5 \mathrm{mM}$ egg PtdCho micelles, but that value increased with cholate concentration, surpassing the value for the native enzyme by more than fourfold in $50 \mathrm{mM}$ cholate $/ 5 \mathrm{mM}$ egg PtdCho micelles. Analogous observations were obtained with $10 \mathrm{mM}$ sodium cholate $/ 3 \mathrm{mM}$ dilauroylphosphoglycerol and $50 \mathrm{mM}$ sodium cholate $/ 3 \mathrm{mM}$ dilauroylphosphoglycerol micelles where dilauroylphosphoglycerol is negatively charged (data not shown). The size and shape of mixed micelles of bile salts with lecithins vary with composition (Mazer et al., 1980; Nichols and Ozarowski, 1990; Shankland, 1970). Molecular masses of $100 \mathrm{kDa}$ and $6.8 \mathrm{kDa}$ were reported for the $10 \mathrm{mM}: 5 \mathrm{mM}$ and $50 \mathrm{mM}: 5 \mathrm{mM}$ cholate/egg PtdCho mixed micelles, respectively (Shankland, 1970). Taken together, these results suggest that (a) activation against zwitterionic ( $\mathrm{Hpo})_{2} \mathrm{Gro} P \mathrm{Cho}$ is not due to a charge effect and (b) micellar packing and/or phospholipid conformation are the probable reasons for the lowered activities in large mixed micelles. The results presented for the native pig enzyme are in agreement with previously reported kinetic studies (Hoffman et al., 1983).

One other study proposed that activation of $\mathrm{PLA}_{2}$ occurred upon acylation of Lys56 (Tomasselli et al., 1989); the acylated enzyme had a high tendency to dimerize and this would be the fully active form of the pancreatic PLA $\mathrm{P}_{2}$ enzyme at interfaces. Several observations support the hypothesis that dimerization is not an issue in this modification: (a) the $\mathrm{pH}$ dependency of the activation (Table 1), (b) increasing protein concentration in the medium lowered the overall activity (Fig. 2), (c) SDS/PAGE of the modified enzyme showed that covalent cross-linking was minimal, (d) PLA that was first immobilized onto agarose beads (Ferreira et al., 1993) was subjected in a second step to the standard chemical modification; the immobilized enzyme, prevented from oligomerization, was activated.

In this study, and in studies with recombinant enzymes (Kuipers et al., 1989; Noel et al., 1991), we find examples of the effects of changes in enzyme conformation in PLA catalysis. However, the reversal in relative activities between modified and native forms in different cholate/egg PtdCho micelles points to the influence of interface quality in the process.

This research was supported by W. R. Grace \& Co. (CT) and funds from the National Institute of Health (GM 25810). J. P. F. also acknowledges Invotan (Portugal) for contribution to his support.

\section{REFERENCES}

Carraway, K. L. \& Koshland, D. E. Jr (1968) Biochim. Biophys. Acta 160, 272-274.

Dijkstra, B. W., Renetseder, R., Kalk, K. H., Hol, W. G. J. \& Drenth, J. (1983) J. Mol. Biol. 168, 163-179. 
Donnée-Op den Kelder, G. M., de Haas, G. H. \& Egmond, M. R. (1983) Biochemistry 22, 2470-2478.

Ferreira, J. P., Sasisekharan, R., Louic, O. \& Langer, R. (1993) Biochemistry 32, 8098-8102.

Fleer, E. A. M., Verheij, H. M. \& de Haas, G. H. (1981) Eur. $J$. Biochem. 113, 283-288.

Hoare, D. G. \& Koshland, D. E. J. (1967) J. Biol. Chem. 242, 24472453.

Hoffman, W. J., Vahey, M. \& Hajdu, J. (1983) Arch. Biochem. Biophys. 221, 361-370.

Jain, M. K., Ranadive, G., Yu, B.-Z. \& Verheij, H. M. (1991) Biochemistry 30, 7330-7340.

Kuipers, O. P., Thunnissen, M. M. G. M., de Geus, P., Dijkstra, B. W., Drenth, J., Verheij, H. B. \& de Haas, G. H. (1989) Science 244, 82-85.

Mazer, N. A., Benedek, G. B. \& Carey, M. C. (1980) Biochemistry $19,601-615$.

Meyer, H., Verhoef, H., Hendriks, F. F. A., Slotboom, A. J. \& de Haas, G. H. (1979) Biochemistry 18, 3582-3588.
Nichols, J. W. \& Ozarowski, J. (1990) Biochemistry 29, 4600-4606.

Noel, J. P., Bingman, C. A., Deng, T., Dupureur, C. M., Hamilton, K. J., Jiang, R.-T., Kwak, J.-G., Sekharudu, C., Sundaralingam, M. \& Tsai, M.-D. (1991) Biochemistry 30, 11801-11811.

Shankland, W. (1970) Chem. Phys. Lipids 4, 109-130.

Staros, J. V., Wright, R. W. \& Swingle, D. M. (1986) Anal. Biochem. $156,220-222$.

Staros, J. V. (1988) Acc. Chem. Res. 21, 435-441.

Tomasselli, A. G., Hui, J., Fisher, J., Zürcher-Neely, H., Reardon, I. M., Oriaku, E., Kézdi, F. J. \& Heinrickson, R. L. (1989) J. Biol. Chem. 264, 10041-10047.

van den Bergh, C. J., Bekkers, A. C. A. P. A., Verheij, H. M. \& de Haas, G. H. (1989) Eur. J. Biochem. 182, 307-313.

Verheij, H. M., Slotboom, A. J. \& de Haas, G. H. (1981) Rev. Physiol. Biochem. Pharmacol. 91, 91-203.

Waite, M. (1987) in The phospholipases (Hanahan, D. J., ed.) Plenum Press, New York. 